\title{
ENERGY EFFICIENT AND ENVIRONMENTALLY FRIENDLY HYBRID CONVERSION OF INLAND PASSENGER VESSEL
}

\author{
Wojciech Litwin \\ Wojciech Leśniewski \\ Jakub Kowalski \\ Gdańsk University of Technology, Faculty of Ocean Engineering and Ship Technology, Poland
}

\begin{abstract}
The development and growing availability of modern technologies, along with more and more severe environment protection standards which frequently take a form of legal regulations, are the reason why attempts are made to find a quiet and economical propulsion system not only for newly built watercraft units, but also for modernised ones. Correct selection of the propulsion and supply system for a given vessel affects significantly not only the energy efficiency of the propulsions system but also the environment - as this selection is crucial for the noise and exhaust emission levels. The paper presents results of experimental examination of ship power demand performed on a historic passenger ship of $25 \mathrm{~m}$ in length. Two variants, referred to as serial and parallel hybrid propulsion systems, were examined with respect to the maximum length of the single-day route covered by the ship. The recorded power demands and environmental impact were compared with those characteristic for the already installed conventional propulsion system.

Taking into account a high safety level expected to be ensured on a passenger ship, the serial hybrid system was based on two electric motors working in parallel and supplied from two separate sets of batteries. This solution ensures higher reliability, along with relatively high energy efficiency.

The results of the performed examination have revealed that the serial propulsion system is the least harmful to the environment, but its investment cost is the highest. In this context, the optimum solution for the ship owner seems to be a parallel hybrid system of diesel-electric type.
\end{abstract}

Keywords: ship propulsion, hybrid propulsion, green shipping, zero emission, solar power

\section{INTRODUCTION}

Mechanically driven ships proved their advantage over sailing ships as early as in the nineteenth century, but sailing cargo ships were still built until the 1930s. However, since the mechanical propulsion has become popular in shipping industry, engineers and designers fast came to the conclusion that the key parameter for a ship is energy efficiency of the entire propulsion system, starting from the engine and ending at the screw propeller. A case which happened in the nineteenth century is known when there was no enough coal for burning steam boilers on a steam ship and the wooden deck was completely burned for this purpose, along with all wooden furniture, to reach the destination. This story may seem funny, and rather unimaginable in these days, when the safety of a ship is controlled by reputable classification societies before they grant the authorisation for placing it into service. Nevertheless, the authors are aware of events when a modern electrically driven ship had to interrupt the voyage, let go the anchor and wait for a tug due to the lack of energy.

In a few recent decades, electric propulsion has successfully been used on ships, especially on special watercraft units such as ice-breakers and warships. In these decades, the development of new technologies has made it possible to design light electric devices with low energy loss. This mainly refers to AC electric motors and frequency converters needed for their control. Despite high price, such solutions are being more and more frequently used now. A good example here 
can be ships designed and built for oil industry, for instance so-called SPV's (Supply Platform Vessels) [1]. The responsibility related with the operation of these vessels affects technical advancement of the installed systems. The construction costs of these vessels are high, but the resultant operating potential is also extremely high, and practically unattainable for earlier designs. An example worth mentioning here is the dynamic positioning system which allows the ship to be kept at a given position, even in storm conditions.

The experience gained in past centuries indicates that each new technology is initially applied in the military industry. The first successful application of a parallel hybrid propulsion system had place in a submarine at the beginning of the twentieth century. For years, electric machines have been improved. Until recently, lead-acid batteries have been used as the energy source in conventional submarines during underwater navigation. And only at the end of the twentieth century attempts were made to install fuel cells [2][3]. Despite the passage of time, the use of fuel cells as energy sources has not become popular in the maritime industry for some reasons, such as high price for instance. As a consequence, those solutions still remain the object of theoretical and experimental research [4][5][6][7].

A significant breakthrough, with serious implications for civil use of hybrid propulsion systems, had place quite recently, due to the development of mobile technologies. Tens of millions of mobile phones, tablets, and portable computers needed a reliable and safe energy source with limited dimensions and mass. The solution was the use of successive generations of lithium batteries. Initially, little attention was paid to the importance of so-called BMS's (Battery Management Systems) controlling the battery charging/discharging processes. However, it soon turned out that these processes have to be permanently controlled, which now is frequently executed by displaying main charging parameters, such as voltage, electric current, and temperature on the screen [8]. At present, hybrid propulsion systems are being developed by various companies all over the world, they are also the object of numerous research activities worldwide [9][10].

For years, a large amount of research has been performed upon photovoltaic panels, which are considered sources of clean, "green" electric energy. Now, they can be seen not only on the roofs of buildings, but also on some vehicles. The voyage of the catamaran PLANETSOLAR around the world, which ended in 2012, is the best example proving that the solar energy can be a significant source of energy for a moving vehicle [11].

An obvious reason why modern hybrid technologies are being more and more widely used is growing awareness of societies regarding the increasing environment pollution, with the resultant more and more severe standards concerning permissible exhaust emission limits. Numerous publications by authors from all over the world can be found in recent literature which focus on economic issues of applications of propulsion systems on inland and sea-going vessels and their effect on the environment [12][13][14][15][16][17]. More and more attention is also paid to noise emission by watercraft units [18][19]. This issue is of special importance in inland navigation, in which the waterways frequently lead through densely urbanised areas. In those conditions, hybrid drive can reveal its advantages. Unlike large water regions, in which high-power diesel engines can generate relatively high ship speeds, canal navigation has often speed restrictions. This prefers the use of quiet and environment friendly electric propulsion systems.

\section{GENESIS OF THE PROJECT}

The authors of the paper have over 10-years' experience in designing and building, together with students of the Gdansk University of Technology, untypical watercraft units with solar energy supplied electric propulsion systems. They witnessed and actively participated in the revolution concerning propulsion and supply of the watercraft used for competitive purposes. During the first edition of the Frisian Solar Challenge - Holland 2006 sailing races, use was usually made of simple brushed DC motors, lead-acid batteries, and components of inland solar systems and photovoltaic panels, the efficiency of which was approximately equal to $10 \%$. By contrast, in 2016 the use of AC motors with permanent rare earth magnets, frequency converters, lithium batteries, and advanced converters of energy generated by photovoltaic panels became a standard in propulsion systems. The average speed on the route of the race, the length of which exceeded $200 \mathrm{~km}$, almost doubled. The maximum speed of the solar energy fed watercraft units taking part in the sailing race in 2016 was greater than $56 \mathrm{~km} / \mathrm{h}$ (Fig.1.). Despite rainy weather, keeping the average speed above $30 \mathrm{~km} / \mathrm{h}$ was quite possible due to the energy accumulated in batteries.

A valuable source of experience was the executed project of the Poland first passenger boat with hybrid propulsion based on solar and power network supply, so-called plug-in hybrid [20].

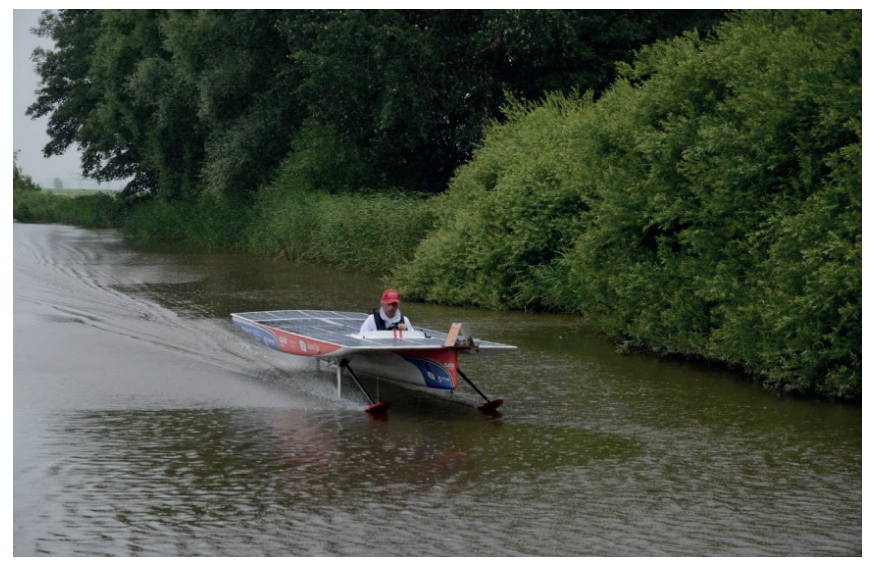

Fig.1. Solar hydrofoil boat "Clafis" during Dutch Solar Challenge 2016

In response to the demand of owners of smaller inland ships, a prototype propulsion system has been designed which 
can be easily installed not only on newly built units, but also, what is more important, on the units already in operation [20]. In the meantime, the classification societies which grant the authorisation for placing the watercraft unit into passenger service radically changed the regulations. Firm emphasis was placed on safety issues. One of key modifications concerned the propulsion system, where a necessary condition became the use of two independent, autonomous propulsion units, which forced in practice the use of two independent diesel engines with independent systems for fuelling, cooling, exhaust, etc.

Changes in regulations have increased the interest of ship owners in new solutions. This especially refers to the owners of ships with propulsion systems based on one, most often, diesel engine. The parallel hybrid propulsion turns out to be able to solve their problems concerning the necessary existence of two independent propulsion units on the ship. Advantages of this solution also are becoming more and more evident for them.

\section{ORIGIN AND PURPOSE}

The authors of the paper have been challenged by the task commissioned by an owner of inland passenger ships to modernise the propulsion system and renovate a historical passenger ship of $25 \mathrm{~m}$ in length. The propulsion of this ship consisted of a $74-\mathrm{kW}$ diesel engine and a single screw propeller, driven via a reduction gear. According to owner's expectations, the new ship propulsion system should be fully electric.

That is why, based on the concept of two engines working for one shafting, which is the solution accepted by classification societies, a propulsion system was proposed in which two electric motors drive a single propeller via a summarising gear. Each motor has an independent supply system, consequently the proposed solution meets the requirements of classification societies concerning passenger ship propulsion, which should consist of two independent systems. Due to the fact that a set of photovoltaic panels, being an additional source of energy, and an emergency power generator are going to be installed on the ship (according to the requirements of the classification society), the propulsion and supply system can be classified as a serial hybrid system. This results from the fact that three sources (network, generator, photovoltaic panels) are used to charge the batteries.

The system in universal configuration is shown in Fig. 2 in the form of block diagram.

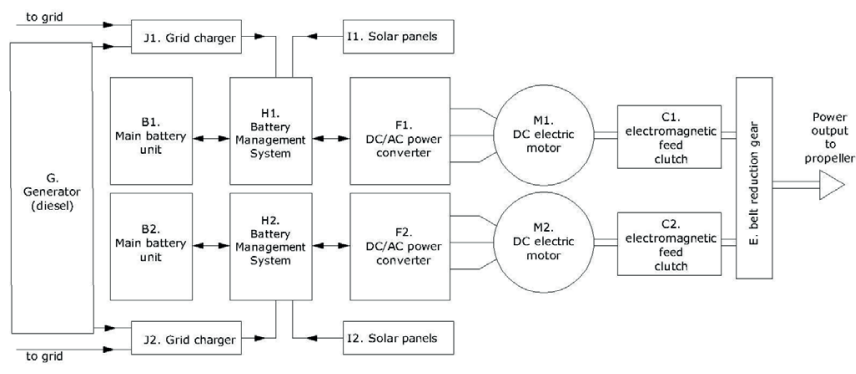

Fig. 2. Modular scheme of the designed propulsion and supply system
Of special interest are the details composing the supply system (modules B, H, I, J). When in use, lithium batteries require an additional Battery Management System (BMS) which protects the entire battery of cells against damage due to overheating or excessively deep charge/discharge by monitoring the operating parameters of each cell. What is also very important is that the BMS controls the charging process in such a way that all cells are equally charged. The latter process is frequently referred to as balancing.

The installed power generator has very important tasks to perform. It is expected to work as emergency power supply in case of complete discharge of the batteries. Even a precisely calculated power balance sheet, along with installation of a larger battery of accumulators, do not ensure sufficient energy reserves to reach the destination in any conditions which may occur during multi-years operation. The next task is ensuring security of the ship and crew, the awareness of which will allow the crew to make rational decisions. What is more, installing the emergency power generator eliminates the risk of an event known from sailing races of solar boats, when the BMS cuts off motor supply a few hundred meters before the finish and the boat begins to drift. This event occurs quite often when the batteries are already heavily discharged and one cell has unacceptably low voltage. There are several possible reasons for this situation, the most frequent of which is that the battery balancing process was not performed during battery charging and significant differences between capacities of individual cells can be observed as a result of poor quality of the cells or their wear-out.

\section{MEASURING POWER DEMAND - EXPERIMENTAL EXAMINATION}

In order to design properly the propulsion and supply system, the experimental examination of the real ship offered by the owner was performed. The goal of this research was to identify the power demand of the ship propulsion system and evaluate the quality of the used screw propeller by calculating its efficiency.

The experiment was executed in the following way: during the voyage, when the ship sailed at constant known speed calculated based on the GPS system, the propeller shaft torque and rotational speed measurements were performed. The torque was measured using the strain gauge method. For this purpose, two double strain gauge sensors, so-called rosettes, were stuck to the propeller shaft. The applied system was unaffected by temperature changes and possible shaft bending.

The measuring system was developed in such a way as to provide opportunity for simultaneous additional measurement of the longitudinal force in the propeller shaft. The known value of the propeller thrust force (i.e. the longitudinal force) made it possible to calculate the so-called "towing power". Comparing the towing power with the power on propeller shaft made it possible, in turn, to calculate the approximate propeller efficiency. 
To allow the measurement, basic components of the recording unit, including:

- strain gauge sensor amplifiers,

- radio transmitter of the measured signal to the recording computer,

- batteries composing the system supply,

were placed on a special handle fixed to the rotating shaft, (Fig. 3).

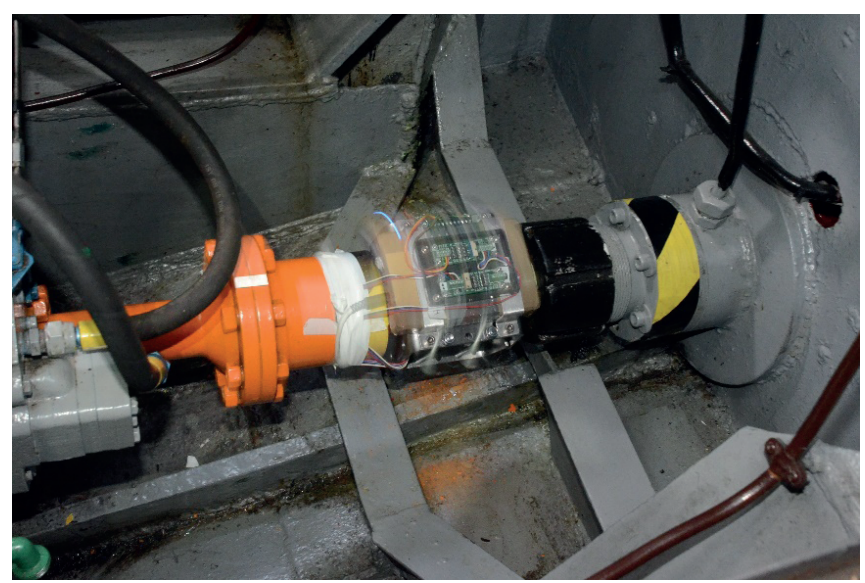

Fig.3. Torque and thrust measurement system rotating with the propeller shaft during the measurements

In order to ensure the highest possible accuracy of measurements, a model of the examined shaft was manufactured in real scale in the laboratory of the Faculty of Ocean Engineering and Ship Technology. The measuring sensors were placed on this model and then loaded in a controlled way to calibrate the system.

Power measurements were done in favourable light-wind conditions. For this purpose, the ship sailed to a sufficiently large water region in which it could sail steady course at a given constant speed for a few minutes. When the ship speed stabilised, its value was estimated from GPS data. Simultaneously, the propeller shaft torque, thrust and rotational speed were measured. To assess the effect of wind, the measurements were done twice: for upwind and downwind course.

The ship speeds for which the measurements were done were equal to $6,8,10,12$ and $13 \mathrm{~km} / \mathrm{h}$. The thrust was measured only for speeds above $10 \mathrm{~km} / \mathrm{h}$, due to the concerns that the measurements of small torque values at lower speeds would be burdened with unacceptably large error resulting from relatively small compressive stresses of the shaft.

The results of the measurements are given in Table 1.

Table 1. Propeller shaft power, towing power, and propeller efficiency calculated from strain gange measurements

\begin{tabular}{|c|c|c|c|c|c|c|}
\hline ship speed & shaft speed & $\begin{array}{c}\text { torque on } \\
\text { propeller } \\
\text { shaft }\end{array}$ & $\begin{array}{c}\text { power on } \\
\text { propeller } \\
\text { shaft }\end{array}$ & $\begin{array}{c}\text { thrust } \\
\text { force in } \\
\text { propeller } \\
\text { shaft } \\
\text { (towing } \\
\text { force) }\end{array}$ & $\begin{array}{c}\text { towing } \\
\text { power }\end{array}$ & $\begin{array}{c}\text { estimated } \\
\text { propeller } \\
\text { efficiency }\end{array}$ \\
\hline $\mathrm{km} / \mathrm{h}$ & $\mathrm{rev} / \mathrm{s}$ & $\mathrm{Nm}$ & $\mathrm{kW}$ & $\mathrm{N}$ & $\mathrm{kW}$ & $\%$ \\
\hline 6,0 & 5,9 & 200,4 & 7,4 & - & - & - \\
\hline 8,0 & 7,4 & 315,1 & 14,6 & - & - & - \\
\hline
\end{tabular}

\begin{tabular}{|c|c|c|c|c|c|c|}
\hline ship speed & shaft speed & $\begin{array}{c}\text { torque on } \\
\text { propeller } \\
\text { shaft }\end{array}$ & $\begin{array}{c}\text { power on } \\
\text { propeller } \\
\text { shaft }\end{array}$ & $\begin{array}{c}\text { thrust } \\
\text { force in } \\
\text { propeller } \\
\text { shaft } \\
\text { (towing } \\
\text { force) } \\
\end{array}$ & $\begin{array}{l}\text { towing } \\
\text { power }\end{array}$ & $\begin{array}{l}\text { estimated } \\
\text { propeller } \\
\text { efficiency }\end{array}$ \\
\hline $\mathrm{km} / \mathrm{h}$ & $\mathrm{rev} / \mathrm{s}$ & $\mathrm{Nm}$ & $\mathrm{kW}$ & $\mathrm{N}$ & $\mathrm{kW}$ & $\%$ \\
\hline 10,0 & 9,8 & 537,9 & 33,2 & 2086,3 & 5,8 & 17 \\
\hline 12,0 & 11,2 & 684,8 & 48,1 & 4526,7 & 15,1 & 31 \\
\hline 13,0 & 12,8 & 919,6 & 73,8 & 6435,9 & 23,2 & 32 \\
\hline
\end{tabular}

What is noteworthy, the sailing resistance characteristic has a typical nonlinear shape (Fig. 4). This is a typical situation in general, but in the examined case it has special meaning. Another noteworthy fact is rapid increase of power demand with the increasing speed, and low propeller efficiency, not exceeding 32\%. This low efficiency results from the use of a very simple welded propeller, the geometry of which was designed using simple parametric methods to estimate ship resistance.

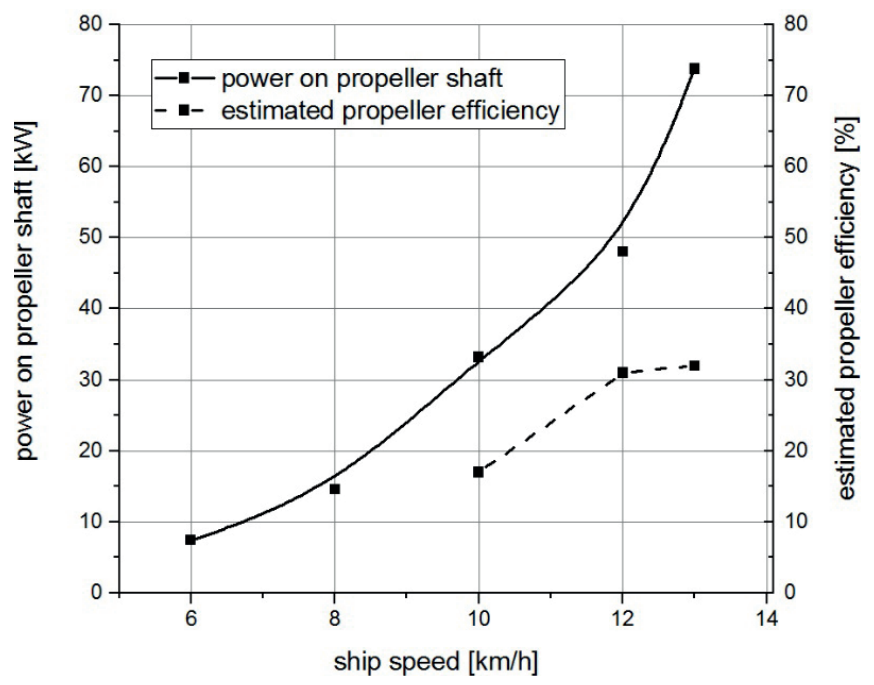

Fig. 4. Measured propeller shaft power and propeller efficiency vs. ship speed

\section{RESULTS AND DISCUSSION}

The examined ship is intended to sail on inland waters, with frequent speed restrictions resulting from the need to protect the shoreline and bed structures. The speed limit in force along a large part of the route leading along historical canals is $6 \mathrm{~km} / \mathrm{h}$. Moreover, it was agreed with the ship owner that the cruising speed of the ship in open waters will be $12 \mathrm{~km} / \mathrm{h}$. Taking into account the experimentally determined towing power equal to $15,1 \mathrm{~kW}$ for the speed of $12 \mathrm{~km} / \mathrm{h}$ (Table 2), and assuming $60 \%$ efficiency of the dedicated screw propeller, the expected mechanical power of the propulsion system was calculated as equal to $25,2 \mathrm{~kW}$. The ship was assumed to be driven by the above described dual propulsion system $2 \times 15 \mathrm{~kW}$, which should provide sufficient power margin and facilitate the performance of manoeuvres. Untypical operating conditions of the ship sailing with two different 
cruising speeds provide opportunities for well-balanced use of the propulsion system, as the lower speed equal to $6 \mathrm{~km} / \mathrm{h}$ is reached by the ship operating on one motor. To reach the higher speed, both motors are to be started up. When analysing the power demand, the longest possible single-day trip of the ship was taken in to account. Its total length is $80 \mathrm{~km}$, with $45 \mathrm{~km}$ leading along canals with speed limits. The diagram in Fig. 5 shows ship speed profiles in different propulsion variants: the presently installed conventional propulsion system, and parallel and serial hybrid systems. Based on the power demand as a function of ship speed, the power demand needed to select battery capacities was calculated, Fig.6. The results of these calculations are given in Table 2. What is noteworthy, decreasing the cruising speed in open waters from 13 to $12 \mathrm{~km} / \mathrm{h}$ leads to substantial energy saving, due to the decreased ship resistance, Fig. 4. The increased travel time in this case, from $10 \mathrm{~h} 10^{\prime}$ to about $10 \mathrm{~h} 30^{\prime}$, seems acceptable.

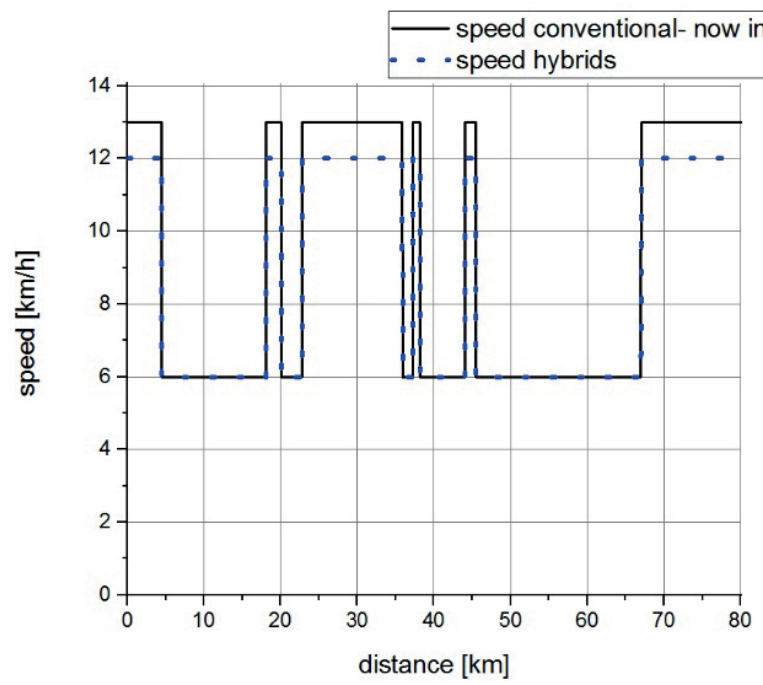

Fig. 5. Diagram of ship speed during longest single-day trip

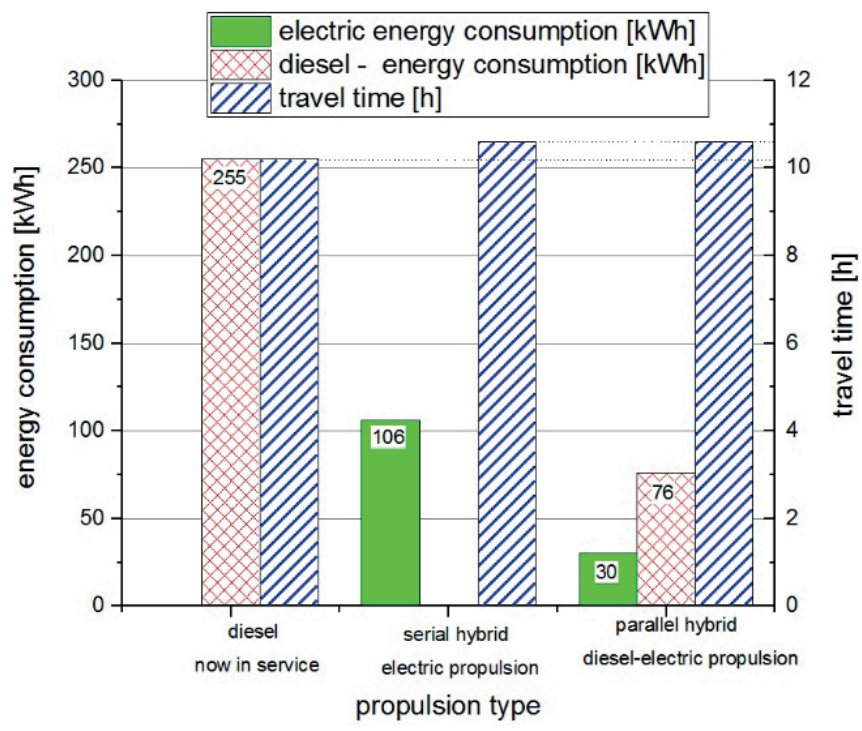

Fig. 6. Power distribution and travel time of longest single-day trip
Table 2. The calculated power demand and electric energy consumption on the ship with hybrid propulsion system

\begin{tabular}{|c|c|c|c|c|c|}
\hline $\begin{array}{c}\text { Ship } \\
\text { speed }\end{array}$ & $\begin{array}{c}\text { Towing } \\
\text { power } \\
\text { (thrust } \\
\text { power) }\end{array}$ & $\begin{array}{c}\text { Propeller } \\
\text { efficiency }\end{array}$ & $\begin{array}{c}\text { Motor } \\
\text { power } \\
\text { (power } \\
\text { on shaft) } \\
{[\mathrm{kW}]}\end{array}$ & $\begin{array}{c}\text { Motor } \\
\text { and } \\
\text { controller } \\
\text { efficiency }\end{array}$ & $\begin{array}{c}\text { Electric } \\
\text { power }\end{array}$ \\
\hline$[\mathrm{km} / \mathrm{h}]$ & {$[\mathrm{kW}]$} & $\%$ & & $\%$ & {$[\mathrm{~kW}]$} \\
\hline 6,00 & 4,00 & 60 & 6,67 & 80 & 8,33 \\
\hline 12,00 & 15,10 & 60 & 25,17 & 85 & 29,61 \\
\hline 13,00 & 23,40 & 60 & 39,00 & 85 & 45,88 \\
\hline
\end{tabular}

What is noteworthy here is low efficiency of the presently used system. The cause for this low efficiency, and the resultant large power consumption, is ineffective screw propeller. Increasing its efficiency from $30 \%$ to $60 \%$ would instantaneously lead to the decrease in fuel consumption even by as much as a half. The energy demand from the serial hybrid system is about $148 \mathrm{kWh}$ (Table 3 ). However, this value was calculated based on $60 \%$ screw propeller efficiency and $100 \%$ efficiency of the electric propulsion system. To calculate the capacity of batteries which are to be installed on the ship, real efficiency of the propulsion system as the function of load is to be taken into account, Fig. 7 .

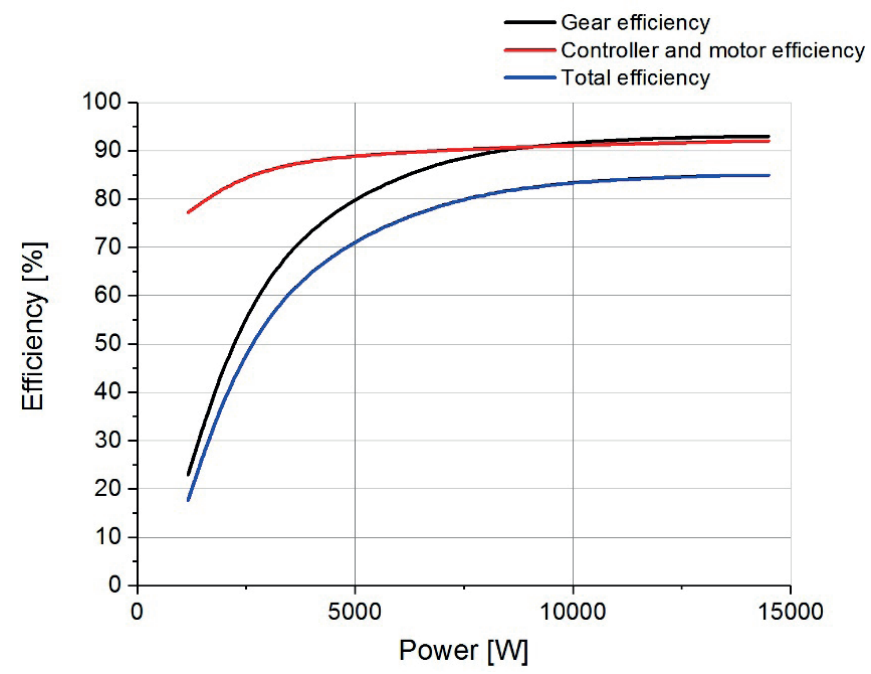

Fig. 7. Propulsion efficiency as a function of power

In practice, at least $20 \%$ battery capacity margin is to be added. The batteries can be installed on the ship but this solution is extremely expensive. The calculated battery capacities are given in Table 3.

Table 3. Calculated power demands for different propulsion types, and capacities of propulsion motor supply batteries

\begin{tabular}{|ll|l|l|}
\hline \multicolumn{1}{|c|}{ Type of drive } & $\begin{array}{c}\text { energy } \\
\text {-diesel } \\
\text { engine } \\
{[\mathrm{kWh}]}\end{array}$ & $\begin{array}{c}\text { energy } \\
\text {-electric } \\
\text { motor }[\mathrm{kWh}]\end{array}$ & $\begin{array}{c}\text { battery } \\
\text { capacity with } \\
20 \% \text { margin } \\
{[\mathrm{kWh}]}\end{array}$ \\
\hline conventional - present state & 260,02 & & \\
\hline $\begin{array}{l}\text { conventional - after screw } \\
\text { propeller replacement }\end{array}$ & 147,78 & & \\
\hline
\end{tabular}




\begin{tabular}{|lc|c|c|}
\hline Type of drive & $\begin{array}{c}\text { energy } \\
\text {-diesel } \\
\text { engine } \\
{[\mathrm{kWh}]}\end{array}$ & $\begin{array}{c}\text { energy } \\
\text {-electric } \\
\text { motor }[\mathrm{kWh}]\end{array}$ & $\begin{array}{c}\text { battery } \\
\text { capacity with } \\
20 \% \text { margin } \\
{[\mathrm{kWh}]}\end{array}$ \\
\hline serial hybrid & 87,9 & 59,88 & 72 \\
\hline parallel hybrid & & 147,78 & 177 \\
\hline
\end{tabular}

The data shown in the table reveals that in terms of investment, a solution which would be favourable for the ship owner is installing the parallel hybrid diesel-electric propulsion. In this case the battery is more than twice as small as for the serial hybrid solution. The size of battery capacity margin can also be reconsidered. It can be small, as the voyage can be continued on a diesel engine in case of battery discharge. Moreover, in the case of parallel hybrid propulsion, when the diesel engine is in operation, the electric motor can be started up in generator mode to charge the batteries during the voyage. This way the size of the battery can be even more reduced, at the expense of its shorter lifetime connected with the number of charging cycles.

What is noteworthy, a relatively large set of light photovoltaic panels can be placed on such a big ship. Their total peak power could reach even as much as $10 \mathrm{~kW}$. In the summer season, at good weather, battery charging from the shore may turn out unnecessary. This solution increases the investment cost, but significantly decreases the operating costs.

Ship reconstruction to pure electric drive eliminates the present exhaust emissions by the conventional low-efficiency propulsion system. The quantity of exhaust emissions for conventional propulsion was calculated using approximate methods [21][22][23]. Real quantities depend on the type of burned fuel and the engine generation [24][25].

Replacing the screw propeller to the dedicated, specially designed unit would reduce the exhaust emissions by half, while applying the parallel hybrid propulsion system would lead to further reduction by $30 \%$ (Fig. 8).

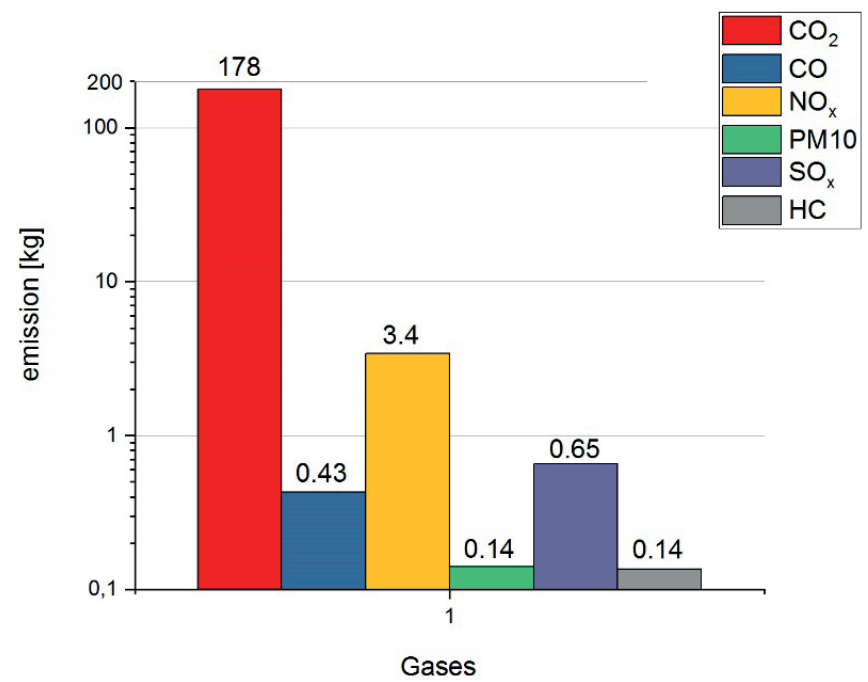

Fig. 8. Calculated exhaust emissions to the atmosphere for different propulsion variants
One more aspect concerning the voyage on the examined ship is worth noticing. The purely electric propulsion makes the ship travel in practically complete silence. The passengers can stay on the weather deck without fear of breathing the exhaust gas.

\section{CONCLUSIONS}

In authors' opinion, reasonably performed ship modernisation consisting in propulsion system replacement from conventional to electric or hybrid system, should involve screw propeller replacement. Only comprehensive modernisation can provide a good effect in the form of decreased consumption of the energy collected in batteries, the amount of which is limited on the ship.

Slower - means more economically. If possible, decreasing the maximal speed is always profitable when the low fuel consumption is a priority.

The propulsion system which seems rational in both operating and investment terms is the parallel hybrid system with battery charging from a set of photovoltaic panels. It should be kept in mind, however, that, for instance, lines of trees growing along the waterway can significantly reduce the amount of energy generated by the panels. It is enough to overshadow a fragment of one panel for the entire set of panels connected in series to stop working. That is why proper connection of panels is crucial for the efficiency of the entire system.

The assumed $20 \%$ battery capacity margin should suffice to cover the increased power demand resulting from, for instance, difficult sailing conditions, ship hull fouling, rapid manoeuvres, and/or minor screw propeller damages which frequently take place during voyages along inland waterways.

\section{REFERENCES}

1. M. C. Díaz-de-Baldasano, F. J. Mateos, L. R. Núñez-Rivas, and T. J. Leo, "Conceptual design of offshore platform supply vessel based on hybrid diesel generator-fuel cell power plant," Appl. Energy, vol. 116, pp. 91-100, 2014.

2. G. Sattler, "Fuel cells going on-board," J. Power Sources, vol. 86, no. 1, pp. 61-67, 2000.

3. A. Psoma and G. Sattler, "Fuel cell systems for submarines: From the first idea to serial production," J. Power Sources, vol. 106, no. 1-2, pp. 381-383, 2002.

4. C. H. Choi et al., "Development and demonstration of PEM fuel-cell-battery hybrid system for propulsion of tourist boat," Int. J. Hydrogen Energy, vol. 41, no. 5, pp. 3591-3599, 2016.

5. Y. M. A. Welaya, M. M. El Gohary, and N. R. Ammar, "A comparison between fuel cells and other alternatives 
for marine electric power generation," Int. J. Nav. Archit. Ocean Eng., vol. 3, no. 2, pp. 141-149, 2011.

6. N.-C. Shih, B.-J. Weng, J.-Y. Lee, and Y.-C. Hsiao, "Development of a small fuel cell underwater vehicle," Int. J. Hydrogen Energy, vol. 38, no. 25, pp. 11138-11143, 2013.

7. N. C. Shih, B. J. Weng, J. Y. Lee, and Y. C. Hsiao, "Development of a $20 \mathrm{~kW}$ generic hybrid fuel cell power system for small ships and underwater vehicles," Int. J. Hydrogen Energy, vol. 39, no. 25, pp. 13894-13901, 2014.

8. C. R. Lashway, A. T. Elsayed, and O. A. Mohammed, "Hybrid energy storage management in ship power systems with multiple pulsed loads," Electr. Power Syst. Res., vol. 141, pp. 50-62, 2016.

9. J. Wilflinger, P. Ortner, R. Johannes, K. Universität, M. Aschaber, and S. Motors, Simulation and control design of hybrid propulsions in boats, vol. 43 , no. Ljung. IFAC, 1999.

10. G. Seenumani, H. Peng, and J. Sun, "A reference governorbased hierarchical control for failure mode power management of hybrid power systems for all-electric ships," J. Power Sources, vol. 196, no. 3, pp. 1599-1607, 2011.

11. Dante D’Orazio, “An inside look at the world's largest solarpowered boat," The Verge, vol. 2013, pp. 1-13, 2013.

12. W. Sihn, H. Pascher, K. Ott, S. Stein, A. Schumacher, and G. Mascolo, "A Green and Economic Future of Inland Waterway Shipping," Procedia CIRP, vol. 29, pp. 317-322, 2015.

13. E. K. Dedes, D. A. Hudson, and S. R. Turnock, "Assessing the potential of hybrid energy technology to reduce exhaust emissions from global shipping," Energy Policy, vol. 40, no. 1, pp. 204-218, 2012.

14. D. A. Cooper, "Exhaust emissions from high speed passenger ferries," Atmos. Environ., vol. 35, no. 24, pp. 4189-4200, 2001.

15. Y. Shi, "Reducing greenhouse gas emissions from international shipping: Is it time to consider market-based measures?," Mar. Policy, vol. 64, pp. 123-134, 2016.

16. J. Yuan, S. H. Ng, and W. S. Sou, "Uncertainty quantification of $\mathrm{CO} 2$ emission reduction for maritime shipping," Energy Policy, vol. 88, pp. 113-130, 2016.

17. B. Zahedi, L. E. Norum, and K. B. Ludvigsen, "Optimized efficiency of all-electric ships by dc hybrid power systems," J. Power Sources, vol. 255, pp. 341-354, 2014.
18. D. Borelli, T. Gaggero, E. Rizzuto, and C. Schenone, "Analysis of noise on board a ship during navigation and manoeuvres," Ocean Eng., vol. 105, pp. 256-269, 2015.

19. A. Badino, D. Borelli, T. Gaggero, E. Rizzuto, and C. Schenone, "Airborne noise emissions from ships: Experimental characterization of the source and propagation over land," Appl. Acoust., vol. 104, pp. 158171, 2016.

20. J. Kowalski, W. Leśniewski, and W. Litwin, "Multi-sourcesupplied parallel hybrid propulsion of the inland passenger ship STA.H. Research work on energy efficiency of a hybrid propulsion system operating in the electric motor drive mode," Polish Marit. Res., vol. 20, pp. 20-27, 2013.

21. I. S. Seddiek and M. M. Elgohary, "Eco-friendly selection of ship emissions reduction strategies with emphasis on SOx and NOx emissions," Int. J. Nav. Archit. Ocean Eng., vol. 6, no. 3, pp. 737-748, 2014.

22. I. S. Seddiek, M. Mosleh, and A. A. Banawan, "Thermoeconomic approach for absorption air condition onboard high-speed crafts,” Int. J. Nav. Archit. Ocean Eng., vol. 4, no. 4, pp. 460-476, 2012.

23. M. Morsy El Gohary and I. S. Seddiek, "Utilization of alternative marine fuels for gas turbine power plant onboard ships," Int. J. Nav. Archit. Ocean Eng., vol. 5, no. 1, pp. 21-32, 2013.

24. M. A. Kalam and H. H. Masjuki, "Emissions and deposit characteristics of a small diesel engine when operated on preheated crude palm oil," Biomass and Bioenergy, vol. 27, no. 3, pp. 289-297, 2004.

25. M. Mikulski, K. Duda, and S. Wierzbicki, "Performance and emissions of a CRDI diesel engine fuelled with swine lard methyl esters-diesel mixture," Fuel, vol. 164, no. x, pp. 206-219, 2016. 


\section{CONTACT WITH THE AUTHORS}

Wojciech Litwin

Wojciech Leśniewski

Jakub Kowalski

Gdansk University of Technology

Faculty of Ocean Engineering and Ship Technology

Gabriela Narutowicza 11/12

80-233 Gdańsk

Poland 